\title{
Transient hyperphosphatasemia in infants and children: a retrospective study of 43 cases
}

\section{Bebek Ve Çocuklarda Geçici Hiperfosfatazemi: 43 Olguluk Retrospektif Bir Çalişma}

\author{
Bahar Çuhacı Çakır ${ }^{1}$, Ceyda Tuna Kırsaçlıoğlư ${ }^{2}$, Emine Kaygı Tartıcı ${ }^{3}$, Fatma Demirel ${ }^{4}$ \\ ${ }^{1}$ Well Child Clinic, Ankara Child Health and Diseases Hematology-Oncology Research and Training Hospital, Ankara, Turkey \\ ${ }^{2}$ Department of Pediatric Gastroenterology, Ankara University, School of Medicine, Ankara, Turkey \\ ${ }^{3}$ Department of Pediatrics, Ankara Child Health and Diseases Hematology-Oncology Research and Training Hospital, Ankara, Turkey \\ ${ }^{4}$ Department of Pediatric Endocrinology, Ankara Child Health and Diseases Hematology-Oncology Research and Training Hospital, Ankara, Turkey
}

Öz

Amaç: Kliniğimizde 3 yıllık bir süre boyunca yüksek plazma ALP düzeylerinin prevalansını ve klinik özelliklerini tanımlamak.

Gereç ve Yöntem: artmış ALP düzeyleri olan 5 yaşın altındaki 533 çocuğunu geriye dönük olarak taradık ve frekans, mevsimsel dalgalanma, yaş dağılımı ve cinsiyet farklılıklarını araştırdık.

Bulgular: Yirmi dört hasta (\% 55.8) kızdı ve yaş ortalaması $7.48 \pm$ 12.77 (1-60) ay idi. Ortalama alkalin fosfataz (ALP) düzeyi 1402.23 \pm $440.4 \mathrm{U} / \mathrm{L}(1038-3135 \mathrm{U} / \mathrm{L})$ ve üst aralıktan $3.33 \pm 1.04$ (2.47-7.46) kat daha yüksekti. ALP seviyeleri, ortalama $2.5 \pm 1.1$ (1-5) aylık bir süre içinde normale döndü.

Sonuç: Bu iyi huylu antitenin erken tanınması, gereksiz testlerden kaçınmaya yardımcı ollabilir.

Anahtar Kelimeler: hiperfosfatazemi, bebeklik, çocuklar

\section{ABSTRACT}

Objective: To describe the prevalence and clinical characteristics of elevated plasma ALP levels during a period of 3 years at our clinic.

Material and Methods: We reviewed 533 children, retrospectively, to investigate the frequency, seasonal fluctuation, age distribution, and sex differences of the patients with the elevated ALP levels in younger than 5 years old children.

Results: Twenty-four of the patients were girls (55.8\%), and the mean age of the patients was $7.48 \pm 12.77$ (1-60) months. The mean serum alkaline phosphatase (ALP) level was $1402.23 \pm 440.4 \mathrm{U} / \mathrm{L}$ (1038-3135 U/L) and it was 3.33 \pm 1.04 (2.47-7.46) fold above upper range. Their ALP levels returned to normal in a mean period of $2.5 \pm$ 1.1 (1 to 5) months.

Conclusion: Early recognition of this benign entity, should help to avoid unnecessary tests.

Keywords: hyperphosphatasemia, infancy, children
Corresponding Author: Bahar Çuhacı Çakır

Address T.C.S.B. Ankara Çocuk Sağlığı ve Hastalıkları Hematoloji Onkoloj Eğitim Araştırma Hastanesi, Ankara, Turkey.

E-mail: baharcc44@yahoo.com
Başvuru Tarihi/Received: 12-02-2016

Kabul Tarihi/Accepted: 22-04-2017 


\section{Introduction}

Transient hyperphosphatasemia (TH) is a benign condition, characterized by transiently increased serum alkaline phosphatase (ALP) [1]. Elevated serum ALP levels occasionally has been occurred with different clinical disorders as gastrointestinal diseases, respiratory infections, congenital anomalies and inborn errors of metabolism, anemia, malignancies, and neurological disorders [2]. Characteristic features of TH previously have been described by Kraut et al [3], include; a) elevation of serum ALP b) no signs of liver, metabolic or bone disease c) age of less than 5 years d) return to normal serum ALP levels within 4 months. The prevalence of $\mathrm{TH}$ ranged 1.5 to $5.1 \%$ in infancy, so recognition of this entity is important to avoid unnecessary tests [3-8].

The aim of this study is to describe the prevalence and clinical characteristics of $\mathrm{TH}$, and to review the published literature.

\section{Material and Methods}

Between January 2011 and January 2014, in our well-child clinic, we studied children who had been taken blood samples for routine screening or minor conditions, retrospectively, to reveal elevated ALP levels in younger than 5 years old children. Serum ALP activity was evaluated by using the ageand gender-specific reference ranges [9]. Children who had any chronic disease (such as chronic liver disease, chronic renal insufficiency, chronic diarrhea, celiac disease, metabolic disease, bone disease ...), using medications which may affect serum ALP levels, did not have follow up measurements were excluded from the study. Children who had no signs of liver, metabolic or bone disease, and return to normal serum ALP levels within 4 months were diagnosed transient hyperphosphatasemia according to Kraut et al [3] definition. A total of 43 patients were recruited to study according to defined criteria.

We investigated seasonal fluctuation, age distribution, and sex differences of the patients with the elevated ALP levels. To analyze the seasonal fluctuation, we arranged the number of cases detected month by month during the study. The definition of the seasons in the Northern hemisphere is; Winter (December-February), Spring (March-May), Summer (July-August) and Autumn (September-November).

The study was approved by Ethics Committee of Ankara Child Diseases Hematology Oncology Training and Research Hospital, Ankara, Turkey.

\section{Statistical Analysis}

All statistical analyses were performed using the SPSS statistical package, version 17.0 for Windows. If the the variables exhibited normal distribution, they were presented by mean and standard deviation (SD), if did not exhibite normal distribution they were presented by median with minimum and maximum levels. Student's $t$-test was used to compare continuous variables and $x^{2}$-test was used to compare categorical variables between two or more groups. If the groups did not exhibit normal distribution, they were analyzed using the Mann-Whitney $U$ test or Kruskal-Wallis test as appropriate. A $p$-value $<0.05$ was considered statistically significant.

\section{Results}

A total of 43 patients [24 (55.8\%) girls] were identified with $\mathrm{TH}$. The median age of the patients was 3 (1-60) months. There was not any significant difference between gender $(p=0.58)$ and age of boys and girls $(8.9 \pm 13.9$ months, $6.3 \pm 11.9$ months, respectively) 
$(p=0.51)$. All patients was found to be in normal weight and height according to their gender and age with normal physical examinations. All patients had unremarkable medical and family history.

Alanine aminotransferase (ALT), aspartate aminotransferase (AST), calcium (Ca), phosphorus $(P)$, urea and creatinin were in normal range in all children (Table 1). Serum 25 -hydroxy vitamin $D$ level was measured in 22 patients $(51.1 \%)$, and was found in normal limits $\quad(38.2 \pm 10.6 \quad \mathrm{ng} / \mathrm{ml}) \quad(22.3-61.5)$. Parathyroid hormone (PTH) was measured in four patients $(9.3 \%)$, all of them were in normal ranges $(29.8 \pm 19.1 \mathrm{pg} / \mathrm{L})$.

Table 1. Laboratory details of patients

\begin{tabular}{|l|l|}
\hline Laboratory tests & 10.6 (9.1-11.1) \\
\hline Calcium (mg/dL)* & $6 \pm 0.8$ \\
\hline Phosphorus (mg/dL)** & $1230(1038-3135)$ \\
\hline Alkaline phosphatase (U/L)* & $37.3 \pm 11.1$ \\
\hline Aspartate aminotransferase (IU/L)** & $23.3 \pm 9.6$ \\
\hline Alanine aminotransferase (IU/L)** & $17(3-94)$ \\
\hline Urea $(\mathrm{mg} / \mathrm{dL})^{*}$ & $0.2(0.05-0.6)$ \\
\hline Creatinine (mg/dL)* & \\
\hline
\end{tabular}

*: Median (Min-Max levels)

$* *$ : Mean \pm SD

The median serum ALP level was 1230 (Min-Max:1038-3135) U/L and it was 3.33 \pm 1.04 (2.47-7.46) fold above upper range. Boys' median ALP level was significantly higher than girls' median ALP level (1305 IU/L [Min-Max:1090-2177], $1172 \mathrm{IU} / \mathrm{L}$ [MinMax:1038-3135]), respectively) ( $p=0.02)$.

The ALP levels returned to within normal limits in mean $2.5 \pm 1.1$ months.

Transient hyperphosphatasemia was mostly seen in children younger than 1-year old $(90.7 \%)$, and only 4 patients were older than 1-year old $(13,27,36$ and 60 months-old, respectively).
We observed a seasonal clustering of cases during winter (34.9\%), and the lowest incidence was in spring $(14 \%)(p=0.54)$.

There wasn't any significant difference in median levels of ALP among seasons $(p=0.7)$ (Table 2).

Table 2. Seasonal variations of ALP levels of patients

\begin{tabular}{|l|l|}
\hline Season ( $\mathrm{n}$ of patients) & ALP level (U/L)* \\
\hline Winter (15) & $1244(1041-1993)$ \\
\hline Spring (6) & $1176(1049-2062)$ \\
\hline Summer (10) & $1248(1038-3135)$ \\
\hline Autumn (12) & $1285(1090-2478)$ \\
\hline$p$ & 0.7 \\
\hline
\end{tabular}

*: Median (Min-Max levels)

\section{Discussion}

Transient hyperphosphatasemia (TH) is a benign disorder, characterized by transiently elevated of 3-50 times upper normal value serum ALP levels, with no evidence for bone or liver diseases, in children younger than five years old $[7,10]$. The prevalence of $\mathrm{TH}$ is reported to be $1.5 \%$ up to $5.1 \%$ during infancy but the real incidence of $\mathrm{TH}$ is not known certainly, because ALP levels is not routinely determined in benign conditions $[5,7,8,11]$. Although, in most of studies, TH affects both sexes equally $[8,11]$, similar like our study, Carroll et al documented a significant male predominance [6]. In previous studies, majority of the $\mathrm{TH}$ were seen in children younger than 2 years old $[4,6]$. Gualco et al revealed, that only $18 \%$ of the cases were older than 37 months, and the median age of their cases was 18 months with ranged from 2 months to 17 years [8].

Serum ALP elevation was mostly 3-5 times higher than the upper reference ranges (12). Gualco et al found, the highest ALP ratio median was 9 with ranges from 2.0-71 fold above upper range [8]. In our study, we found 3.33 fold above upper range. 
Serum ALP is produced in the liver, bone, intestine and the placenta $[8,10,13]$. In pediatric patients [14], the bone and liver fractions of ALP contribute $85 \%$ and $15 \%$, respectively [13]. The serum ALP levels change with age (12). Because of higher rates of osteoblastic activity in children, serum ALP levels are higher than adults $[14,15]$. In infancy, ALP levels are threefold the upper reference limit for adults, by the 2-years of age, serum ALP levels begin to fall and during puberty, ALP levels increase again $[1,7,8,13]$. Gualco et al, indicated that, ALP isoenzyme studies are not useful in clinical practice to evaluate subjects with $\mathrm{TH}[8,15]$.

The etiology of $\mathrm{TH}$ seems to be multifactorial. Although it is in high concentrations in growing bone and in bile, ALP is a marker of hepatic and metabolic bone disorders [10]. We found, the levels of $\mathrm{Ca}, \mathrm{P}$ and PTH (four patients) in normal ranges, thus ruling out increased bone turnover. Respiratory and gastrointestinal infections, mostly viral, seem to be important triggering factors in $\mathrm{TH}$ without any underlying chronic disease $[8,10,13,16]$. Although an association between $\mathrm{TH}$ and failure to thrive was found in previous studies [6,7], but we did not observe it.

However it has occurred in association with some clinical conditions, including liver diseases, malignancy, rickets and other metabolic osseous diseases, drugs as cotrimaxazole, albumin, cyclosporin $\mathrm{A}$, anticonvulsants and following organ transplantation $[7,8,13,15]$. Although, failure to thrive was the one of the possible cause of TH [6], in our study we did not observe it. But mostly, TH has been seen without any underlying condition (87\%) [8].

A seasonal peak was observed during the winter in our study. This seasonal predilection may be associated with frequency of infections during fall and winter as shown previous studies $[6,8,16]$. Although, in another study, 2 peaks were shown in spring and fall [17], some authors were not found seasonal variation $[4,6]$.

The duration of TH may be associated the duration of bone resorption cycle, which takes 4 months [10]. Although, most of the ALP levels return to normal earlier than 4-6 months $[8,13]$, in one study, authors revealed that, the duration of the elevation ranged from 2 weeks to 4 years with median 10 weeks [8]. Also, $20 \%$ of the cases persist for longer than 17 weeks [8]. We found the mean duration of TH was shorter than previous studies (2.5 \pm 1.1 months). Unfortunately, exact maximal ALP levels and the duration of $\mathrm{TH}$ are difficult to determine because of the incidental detection of this state.

Our study had some limitations. Because of this is a retrospective study, in most patients, we could not assess, 25-hydroxy vitamin D, PTH and alkaline phosphatase isoenzymes.

In conclusion; $\mathrm{TH}$ is a transient, benign and self-limited condition. The diagnosis of $\mathrm{TH}$ was based on normalization of serum ALP levels within 4-6 months and no evidence for bone or liver diseases on physical examination and laboratory findings may be useful clinically.

\section{References}

1. Tolaymat $\mathrm{N}$, de Melo MC. Benign transient hyperphosphatasemia of infancy and childhood. South Med J 2000; 93: 1162-64.

2. Behúlová $D$, Bzdúch $V$, Holesová $D$, et al. Transient hyperphosphatasemia of infancy and childhood: study of 194 cases. Clin Chem 2000; 46: 1868-69.

3. Kraut JR, Metrick M, Maxwell NR, et al: Isoenzyme studies in transient hyperphosphatasemia of infancy. ten new cases and a review of the literature. Am J Dis Child 1985; 139:736-740 
4. Huh SY, Feldman HA, et al. Prevalence of transient hyperphosphatasemia among healthy infants and toddlers. Pediatrics 2009; 124: 703-9.

5. Teitelbaum JE, Laskowski A, Barrows FP. Benign transient hyperphosphatasemia in infants and children: a prospective cohort. J Pediatr Endocrinol Metab 2011; 24: 351-3.

6. Carroll AJ, Coakley JC. Transient hyperphosphatasaemia: an important condition to recognize. J Paediatr Child Health 2001; 37: 359-62.

7. Otero JL, González-Peralta RP, Andres JM, et al. Elevated alkaline phosphatase in children: An algorithm to determine when a "Wait and See" approach is optimal. Clin Med Insights Pediatr 2011; 5: 15-8.

8. Gualco G, Lava SA, Garzoni L, et al. Transient benign hyperphophatasemia. J Pediatr Gastroenterol Nutr 2013; 57: 167-71.

9. Lo SF. Reference Intervals for Laboratory Tests and Procedures. In: Behrman RE, Kliegman RM, Jenson HB, eds. Nelson Textbook of Pediatrics, 19th ed. Philadelphia: WB Saunders, 2011: 2466.

10. Kutilek S, Cervickova B, Bebova P, et al. Normal bone turnover in transient hyperphosphatasemia. J Clin Res Pediatr Endocrinol 2012; 4: 154-6.

11. Stein P, Rosalki SB, Foo AY, et al. Transient hyperphosphatasemia of infancy and early childhood: clinical and biochemical features of 21 cases and literature review. Clin Chem 1987; 33: 313-8.

12. Eymann A, Cacchiarelli N, Alonso G, et al. Benign transient hyperphosphatasemia of infancy. A common benign scenario, a big concern for a pediatrician. J Pediatr Endocrinol Metab 2010; 23: 927-30.

13. Turan S, Topcu B, Gökçe i, et al. Serum alkaline phosphatase levels in healthy children and evaluation of alkaline phosphatase z-scores in different types of rickets. J Clin Res Pediatr Endocrinol 2011; 3: 7-11.

14. Suzuki M, Okazaki T, Nagai T, et al. Viral infection of infants and children with benign transient hyperphosphatasemia. FEMS Immunol Med Microbiol 2002; 33: 215-8. 